\title{
RADIOCARBON DATING OF THE ZAGREB UPPER TOWN PREHISTORIC SETTLEMENT
}

\author{
BOGOMIL OBELIĆ, , MARIJA ŠMALCELJ, ${ }^{2}$ NADA HORVATINČIĆ, ${ }^{1}$ ROMANA BISTROVIĆ' \\ and ADELA SLIEPČEVIĆ ${ }^{3}$
}

\begin{abstract}
During the 1989-1994 renovation of the Zagreb Town Museum, it became obvious that the area was inhabited in prehistoric times. We ${ }^{14} \mathrm{C}$ dated 40 samples to determine various settlement periods. The ages of the samples span a much longer time than expected, from the Early Iron Age (Hallstatt period) to the 19 th century $\mathrm{AD}$. ${ }^{14} \mathrm{C}$ dates on charcoal samples placed the remains of dwelling pits in the Hallstatt period, 8th to 4th century BC. A late La Tene settlement dated between the 4th century BC and the 2nd century AD. Medieval fortifications were identified in the western part of the complex, consisting of a well-preserved wooden structure used for construction of the royal castrum. ${ }^{14} \mathrm{C}$ measurements on wooden planks and posts date the construction of the fortification between the 13th and 15th centuries $\mathrm{AD}$ and branches, beams, and tools found below the basement of the Convent of St. Clare span the 16th to the 19th century AD.
\end{abstract}

\section{INTRODUCTION}

The Zagreb Town Museum was completely renovated for the 900th anniversary of the capital of Croatia. The Museum is located in a historical complex on the northeast corner of Gradec Hill (167 $\mathrm{m}$ asl) and includes the 13th century watchtower Popov Toranj, a former Convent of St. Clare and the Old Town granary (Fig. 1). Following preliminary archaeological excavations in 1989, M. Šmalcelj supervised systematic investigations from 1991-1994. Archaeological finds showed that the Gradec hilltop was inhabited during the Hallstatt (Early Iron Age, 8th-5th century BC), La Tène (Late Iron Age, 3rd-1st century BC) and the Middle Ages.

The toponym Zagreb is mentioned for the first time in a document related to the foundation of the diocese and the erection of the first cathedral on the Kaptol hill by Hungarian King Ladislas (10401095 ) in AD 1094. Another important date is AD 1242, when Hungaro-Croatian King Bela IV briefly stopped in Zagreb on his escape to the Adriatic Sea, fleeing the advancing Tartars. After Gnengis Khan's death, King Bela IV, in a proclamation known as the "Golden Bull", freed several towns that offered shelter during his exile, including Zagreb. The town developed on top of Gradec Hill, surrounded by ramparts, which were strengthened during the time of danger from the Ottoman Turks (15th-17th century). The canons of the Zagreb Chapter built a watchtower and owned several houses at the northeast corner of the hill. The danger from the Ottoman Turks being over, the canons' property was given, according to the decision of the Croatian Parliament in AD 1635, to the Order of St. Clare, who built a convent $c a$. AD 1650. Following the secularization proclaimed by Austrian Emperor Joseph II, the convent was converted into barracks and a post station and finally, during this century, into the Town Museum.

\section{ARCHAEOLOGICAL INVESTIGATIONS}

The excavations at Gradec Hill revealed the remains of a relatively large Early Iron Age (Hallstatt) settlement. The remains of older dwelling pits are partly overlain by houses with stone basements and fireplaces. A well-preserved furnace for bronze melting found on this site probably belongs to this period. A late La Tène settlement was built on the same site just before the Roman conquest of the Illyricum. Well-preserved fortifications show a construction technically unknown to this part of

\footnotetext{
${ }^{1}$ Rudjer Boškovic Institute, P.O.B. 1016, 10001 Zagreb, Croatia

${ }^{2}$ Faculty of Philosophy, Department of Archaeology, Ivana Lucica 3, 10000 Zagreb

${ }^{3}$ Faculty of Veterinary Sciences, Department of Physics, Heinzelova 55, 10001 Zagreb
} 


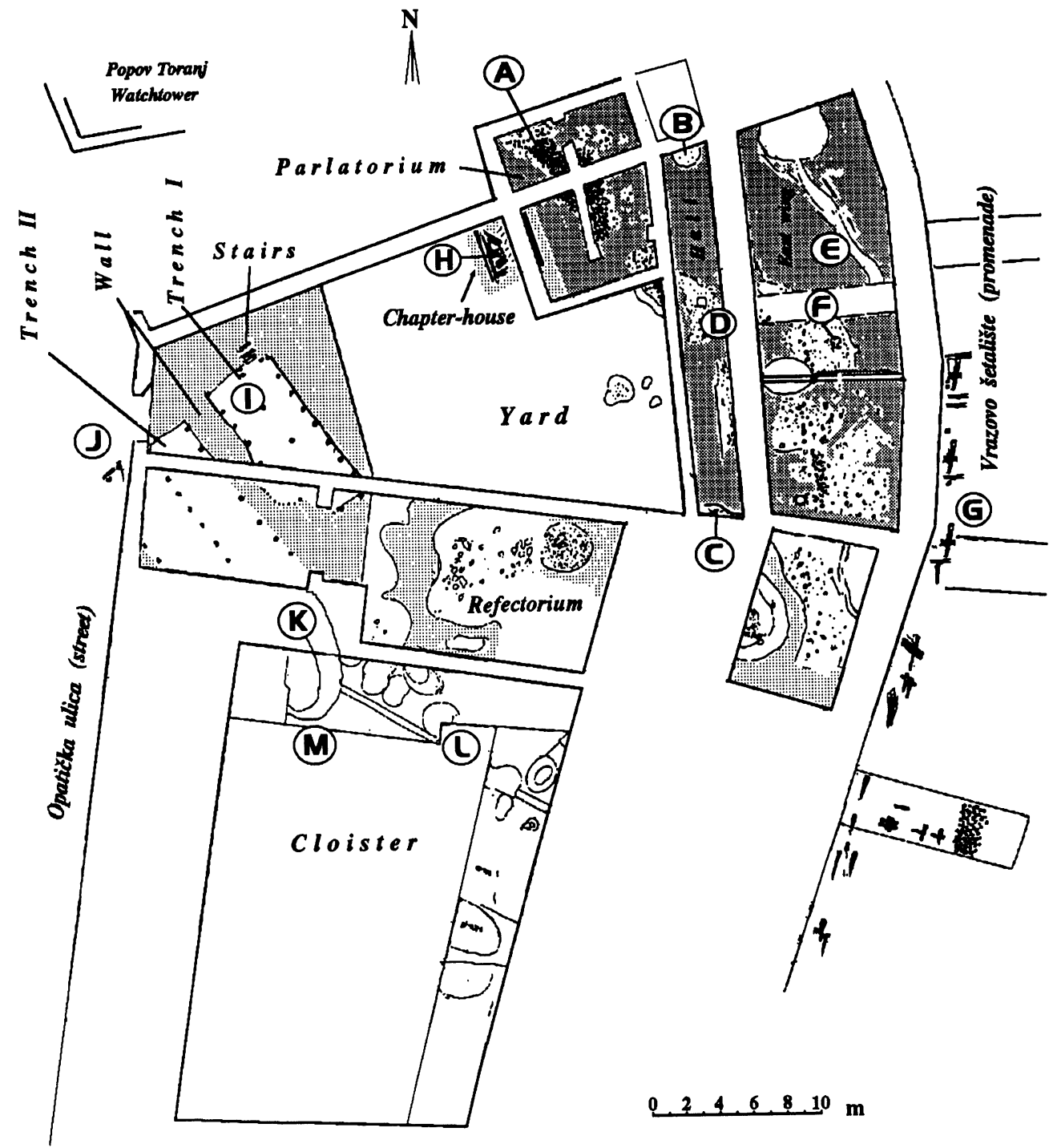

Fig. 1. Site plan of the former Convent of St. Clare, Zagreb Upper Town. Letters denote ${ }^{14} \mathrm{C}$ sampling sites. A-G: prehistoric sites; H-M: medieval sites. Parlatorium = parlor, room in a monastery (or convent) where visitors can speak with monks or nuns; Refectorium $=$ refectory, dining room in a monastery.

Europe. The circumvallation was built by burning the massive wooden construction filled with marly clay. The remains of buildings with walls made of thin wooden posts were found inside the fortification. This settlement was abandoned and the remains were leveled during construction of a medieval fortification during the 11th and 12 th centuries. The remains of a well-preserved wooden structure that supported the earthwork of the royal castrum (fortification) were discovered in the northwestern section. Two square trenches, $1.0-1.5 \mathrm{~m}$ deep, separated by a clay wall $2.5 \mathrm{~m}$ thick, were probably used for collecting rainwater and were parts of the town fortification (probably guardhouses near the town gate). 
The rectangular trench on the east side (Trench I, Fig. 1), $8.50 \mathrm{~m}$ long and $4.50 \mathrm{~m}$ wide, containing three rows of vertical pilings driven into the clay, probably served as a cistern. A set of horizontal tongue-and-groove boards supported the clay wall. Wooden steps leading down to the trench and the remains of a wooden door and door frame were also found. The door probably served as a gate during high water level in the cistern.

Trench II (Fig. 1) consists of three rows of posts running northwest-southeast, as in Trench I, and is located at the extreme west wall of the convent under which the cistern runs. A continuous row of tongue-and-groove boards, as clearly seen in the first trench, was not found here. Over the centuries, mud was deposited within the system of trenches. The finds include large amounts of building material, coarse household ceramics, iron tools, stone catapult balls and a relatively large number of organic remains, including peach pits, nuts, a Sorghum broom, and bones of mammals and poultry.

This part of the Old Town, which had belonged to the Zagreb Canons since the 13th century, was destroyed at the beginning of the 15 th century when the building of the stone circumvallation was finished. The evidence for this is coins of the Hungaro-Croatian King Sigismund of Luxembourg (1368-1437) minted in 1427 found in a layer of clay beneath the structure. Some wood from the town was reused in a smaller building nearby.

At the convent parlatorium (a "parlor" or meeting-room) were found two beams and some boards in the cellar of a wooden house, constructed in 15 th century, which belonged to the Chapter. The cellar was half-open toward the south. It seems that the boards, all $c a .1 \mathrm{~m}$ long, were used as roof shingles, taken from the older, destroyed fortification, and that they were thrown into the trench during reconstruction. During excavations at the present-day cloister, pits were found under the existing foundations. Some of the pits were probably used for local industry, such as leather tanning, and later were filled with waste. In one pit, the remains of a colored eggshell were found. Pit No. 3 contained a ceramic jug with the inscription, $\mathrm{AD} 1615$, in baroque letters.

\section{METHODS}

\section{Excavations}

Excavations were done by strictly demarcating separate, successive layers. We took special care to identify the levels at which individual diggings were done for both houses (La Tène houses excavated in the Hallstatt layer) and postholes or pits. Both horizontal (planum) and vertical sections were prepared for each layer.

Most of the 40 samples dated at the Ruđer Boškovic Institute were wood from beams and boards, and charcoal. Samples of charcoal were taken exclusively from complete, intact layers. One bone sample and one sample of Sorghum from a broom were also analyzed. Due to the influence of groundwater, the wood samples were well preserved, most of them showing individual tree rings, which enabled dendrochronological dating.

\section{Radiocarbon Dating}

Charcoal and wood samples were pretreated by standard acid-base-acid procedures. The collagen fraction of the bone was separated following the Longin method (1971). Further processing included sample combustion, catalytic hydrogenation of $\mathrm{CO}_{2}$ to $\mathrm{CH}_{4}$, and measurement in a proportional counter for $24 \mathrm{~h}$ following methods published previously (Srdoč, Breyer and Sliepčević 1971). After preparation, samples were stored for at least 14 days to allow radon to decay (Horvatinčic et al. 1995). Samples were measured at least twice. Mean values and standard deviations were calculated using standard uncertainty propagation methods (Obelić 1990). Results are given in uncalibrated 
"years" BP using the Libby half-life, 5568 yr. No ${ }^{13} \mathrm{C}$ measurements were performed, but $\delta^{13} \mathrm{C}$ corrections were applied according to Stuiver and Polach (1977). The ${ }^{14} \mathrm{C}$ ages were dendrochronologically calibrated based on a $68.3 \%$ confidence level $(1 \sigma)$, using the probability method $(B)$ of the Stuiver and Reimer (1993) CALIB 3.0.3 program.

The reliability of the measurements was tested by three successive intercomparison studies (Scott $e t$ al. 1990). These studies show that our results are, in all cases, equivalent to median values for participating laboratories (Krajcar Bronić et al. 1995).

Table 1 lists the results, which include calibrated age ranges (68.3\% confidence level) and dating probabilities (in \%) for the corresponding relative areas of the probability distributions. Calibrated ranges with relative areas $<15 \%$ are omitted.

TABLE $1 .{ }^{14} \mathrm{C}$ Dating Results from the Zagreb Upper Town

\begin{tabular}{|c|c|c|c|c|c|}
\hline Site & $\begin{array}{l}\text { Lab no. } \\
\text { (Z-) }\end{array}$ & Sample material & $\begin{array}{c}{ }^{14} \mathrm{C} \text { age } \\
(\mathrm{BP})\end{array}$ & $\begin{array}{l}\text { Calibrated age rang } \\
\text { (with relative areas }\end{array}$ & $\begin{array}{l}\text { ages* } \\
\text { in \%) }\end{array}$ \\
\hline \multicolumn{6}{|c|}{ Prehistoric Samples } \\
\hline $\begin{array}{l}\text { A } \\
\text { A } \\
\text { A } \\
\text { A } \\
\text { B }\end{array}$ & $\begin{array}{l}2448 \\
2449 \\
2450 \\
2451 \\
2452\end{array}$ & $\begin{array}{l}\text { Charcoal } \\
\text { Charcoal } \\
\text { Charcoal } \\
\text { Charcoal } \\
\text { Charcoal (lower) }\end{array}$ & $\begin{array}{l}2085 \pm 100 \\
2040 \pm 110 \\
1750 \pm 105 \\
1770 \pm 95 \\
2340 \pm 115\end{array}$ & $\begin{array}{l}\text { cal BC } 200-A D 28 \\
\text { cal BC } 185-A D 80 \\
\text { cal AD 196-415 } \\
\text { cal AD 193-389 } \\
\text { cal BC 535-344 }\end{array}$ & $\begin{array}{l}(94) \\
(100) \\
(93) \\
(89) \\
(57)\end{array}$ \\
\hline B & 2453 & (upper) & $2100 \pm 90$ & $\begin{array}{c}318-204 \\
\text { cal BC 202-AD } 13\end{array}$ & $(30)$ \\
\hline C & 2454 & Charcoal & $2375 \pm 105$ & $\begin{array}{l}\text { cal BC 202-AD } 13 \\
\text { cal BC 760-673 }\end{array}$ & $\begin{array}{l}(96) \\
(24)\end{array}$ \\
\hline $\mathrm{C}$ & 2463 & W & & 559-365 & $(65)$ \\
\hline $\mathrm{C}$ & 2457 & $\begin{array}{l}\text { Wood } \\
\text { Charc }\end{array}$ & $2255 \pm 110$ & cal BC 405-156 & (92) \\
\hline D & 2458 & Charcoal & $\begin{array}{l}2590 \pm 130 \\
2450 \pm 110\end{array}$ & $\begin{array}{l}\text { cal BC } 846-515 \\
\text { cal BC 760-672 }\end{array}$ & $\begin{array}{l}(99) \\
(31)\end{array}$ \\
\hline D & 2459 & $\begin{array}{l}\text { dation pit } \\
\text { Charcoal }\end{array}$ & $2290 \pm 105$ & $\begin{array}{r}562-407 \\
\text { cal BC } 424-177\end{array}$ & $\begin{array}{l}(54) \\
(91)\end{array}$ \\
\hline D & 2455 & Charcoal (upper) & $1990 \pm 100$ & cal BC 109-AD 133 & $(100)$ \\
\hline D & 2456 & Charcoal (lower) & $2110 \pm 100$ & cal BC 207-AD 10 & $(88)$ \\
\hline E & 2460 & Burned oak & $1745 \pm 135$ & cal AD 129-433 & (100) \\
\hline $\mathrm{F}$ & 2461 & Round logs & $1630 \pm 105$ & cal AD 330-550 & (95) \\
\hline G & 2482 & trunk & $2220 \pm 90$ & cal BC $382-178$ & (100) \\
\hline G & 2483 & Burned trunk & $2500 \pm 105$ & cal BC 784-512 & (99) \\
\hline G & 2484 & Burned trunk & $2215 \pm 110$ & cal BC $390-154$ & (94) \\
\hline G & 2485 & Burned trunk & $2310 \pm 160$ & cal BC 545-167 & (86) \\
\hline G & 2486 & Burned tr & $2250 \pm 110$ & cal BC 403-156 & (96) \\
\hline G & 2487 & Burned trunk & $2215 \pm 90$ & cal BC $380-174$ & $(100)$ \\
\hline G & 2488 & Burned trunk & $2300 \pm 105$ & cal BC 426-190 & (86) \\
\hline G & 2490 & Burned trunk & $2400 \pm 145$ & cal BC 764-615 & (38) \\
\hline & & & & $606-379$ & $(62)$ \\
\hline \multicolumn{6}{|c|}{ Medieval Samples } \\
\hline $\mathrm{H}$ & 2280 & Board (Tr. 12) & $300 \pm 75$ & $\begin{array}{l}\text { cal AD1487-1609 } \\
1611-1663\end{array}$ & $\begin{array}{l}(69) \\
(31)\end{array}$ \\
\hline H & 2286 & Board (Tr. 12) & $325 \pm 80$ & cal AD1487-1648 & $(100)$ \\
\hline
\end{tabular}


TABLE 1. (Continued)

\begin{tabular}{|c|c|c|c|c|c|}
\hline Site & $\begin{array}{l}\text { Lab no. } \\
\text { (Z-) }\end{array}$ & Sample material & $\begin{array}{c}{ }^{14} \mathrm{C} \text { age } \\
(\mathrm{BP})\end{array}$ & $\begin{array}{l}\text { Calibrated age ran } \\
\text { (with relative areas }\end{array}$ & $\begin{array}{l}\text { nges* } \\
\text { s in \%) } \\
\end{array}$ \\
\hline $\mathrm{H}$ & 2285 & Board (Tr. 26) & $264 \pm 105$ & $\begin{array}{l}\text { cal AD1489-1607 } \\
1612-1683\end{array}$ & $\begin{array}{l}(42) \\
(29)\end{array}$ \\
\hline $\begin{array}{l}\text { I } \\
\text { I }\end{array}$ & $\begin{array}{l}2369 \\
2409\end{array}$ & $\begin{array}{l}\text { Wooden post } \\
\text { Board }\end{array}$ & $\begin{array}{l}765 \pm 50 \\
605 \pm 80\end{array}$ & $\begin{array}{l}1745-1807 \\
\text { cal AD } 1233-1289 \\
\text { cal AD 1305-1367 }\end{array}$ & $\begin{array}{l}(22) \\
(100) \\
(66)\end{array}$ \\
\hline I & 2411 & Board, door frame & $580 \pm 90$ & $\begin{array}{r}1373-1405 \\
\mathrm{cal} \text { AD } 1306-1365 \\
1375-1424\end{array}$ & $\begin{array}{l}(34) \\
(55)\end{array}$ \\
\hline $\begin{array}{l}\text { I } \\
\text { I }\end{array}$ & $\begin{array}{l}2412 \\
2405\end{array}$ & $\begin{array}{l}\text { Door } \\
\text { Twigs }\end{array}$ & $\begin{array}{l}795 \pm 70 \\
480 \pm 115\end{array}$ & $\begin{array}{r}1375-1424 \\
\text { cal AD } 1183-1289 \\
\text { cal AD 1391-1519 }\end{array}$ & $\begin{array}{l}(44) \\
(90) \\
(69)\end{array}$ \\
\hline I & 2407 & Bone & $540 \pm 80$ & $\begin{array}{r}1573-1626 \\
\mathrm{cal} A D 1309-1356\end{array}$ & $\begin{array}{l}(20) \\
(38)\end{array}$ \\
\hline I & 2413 & Sorghum & $430 \pm 85$ & $\begin{array}{r}1383-1444 \\
\mathrm{cal} A D 1421-1520\end{array}$ & $\begin{array}{l}(62) \\
(67)\end{array}$ \\
\hline I & 2408 & Wooden board & $216 \pm 119$ & $\begin{array}{r}1571-1626 \\
\text { cal AD } 1634-1709 \\
1711-1822\end{array}$ & $\begin{array}{l}(31) \\
(26) \\
(40)\end{array}$ \\
\hline J & 2410 & Wooden post & $440 \pm 80$ & $\begin{array}{r}1834-1881 \\
\mathrm{cal} \text { AD } 1413-1517\end{array}$ & $\begin{array}{l}(15) \\
(77)\end{array}$ \\
\hline K & 2417 & $\begin{array}{l}\text { Wood below colored } \\
\text { eggshell (Pit 1) }\end{array}$ & $330 \pm 85$ & $\begin{array}{r}1583-1623 \\
\mathrm{cal} \text { AD } 1481-1649\end{array}$ & $\begin{array}{l}(23) \\
(100)\end{array}$ \\
\hline K & 2414 & Wood (Pit 2) & $275 \pm 114$ & cal AD 1480-1682 & (75) \\
\hline $\mathrm{L}$ & 2416 & $\begin{array}{l}\text { Wooden post } \\
\text { (Pit 2) }\end{array}$ & $280 \pm 80$ & $\begin{array}{r}1748-1805 \\
\text { cal AD } 1489-1606 \\
1612-1674\end{array}$ & $\begin{array}{l}(19) \\
(55)\end{array}$ \\
\hline $\mathbf{M}$ & 2415 & $\begin{array}{l}\text { (Pit 2) } \\
\text { Wood (Pit 3) }\end{array}$ & $375 \pm 80$ & $\begin{array}{r}1612-1674 \\
\text { cal AD } 1452-1526\end{array}$ & $\begin{array}{l}(32) \\
(49)\end{array}$ \\
\hline $\mathbf{M}$ & 2425 & Straw (Pit 3) & $120 \pm 80$ & $\begin{array}{r}1556-1632 \\
\mathrm{cal} \text { AD } 1684-1743 \\
1807-1932\end{array}$ & $\begin{array}{l}(51) \\
(32) \\
(68)\end{array}$ \\
\hline
\end{tabular}

Figure 2 shows all the ${ }^{14} \mathrm{C}$ measurements of this study. They span an interval from the 9 th century $\mathrm{BC}$ to the 18 th century $\mathrm{AD}$. No samples with calibrated ages covering the 5 th to 11 th centuries were found.

\section{Discussion}

The remains of a hearth were found below the foundations of the convent parlatorium (A in Fig. 1). Charcoal found beneath a Hallstatt bowl (Z-2448: $2085 \pm 100 \mathrm{BP}$ ), as well as another charcoal sample (Z-2449: $2040 \pm 110 \mathrm{BP})$ from the same cultural layer date to the La Tène, thus supporting the archaeological age estimates. However, two samples from the same layer (Z-2450: $1750 \pm 105$ $\mathrm{BP}$ and Z-2451: $1770 \pm 95 \mathrm{BP}$ ) yielded ages from the 2nd-4th century AD, which were not confirmed by archaeological finds. 


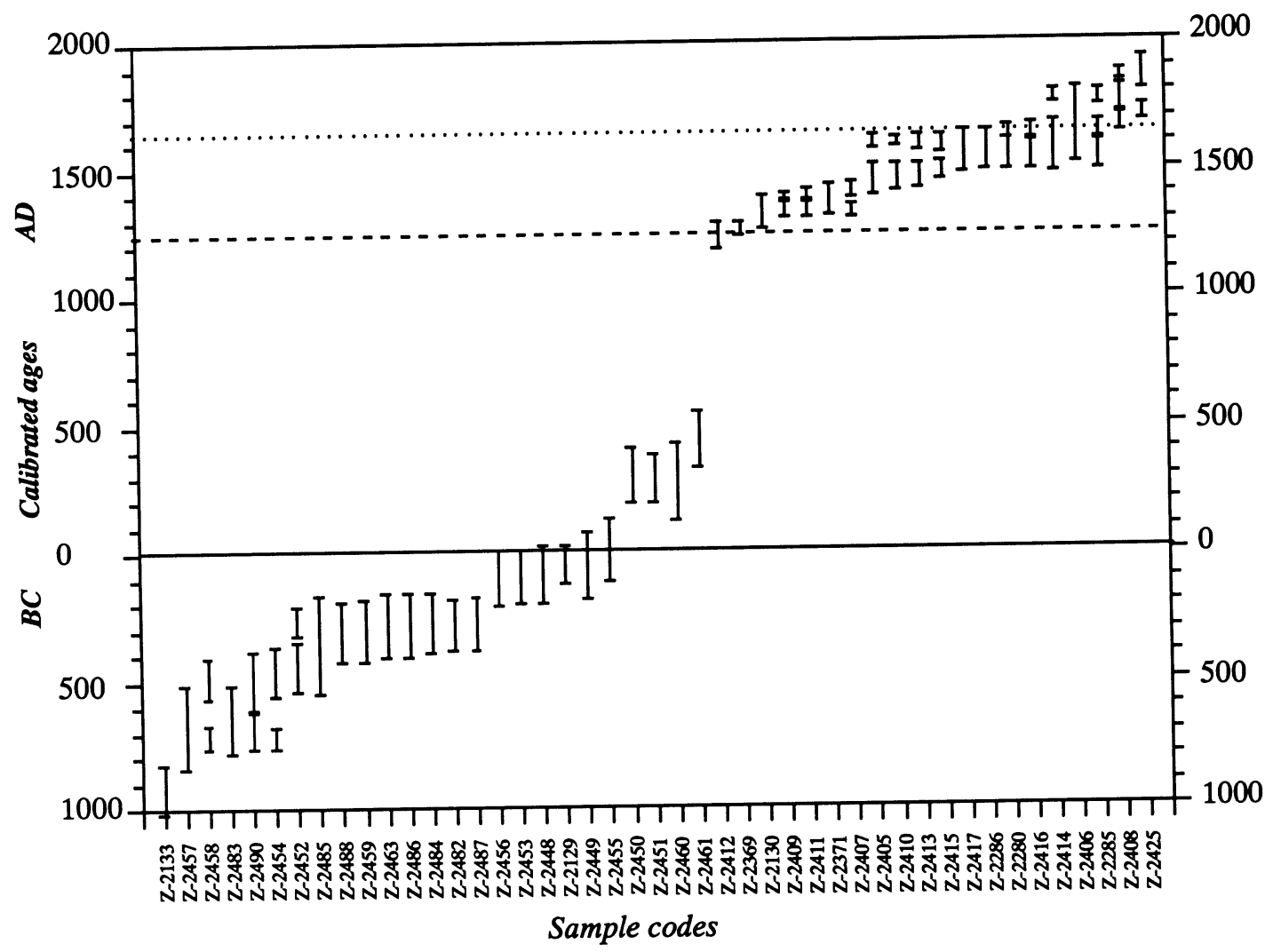

Fig. 2. Calibrated age ranges for results listed in Table 1, sorted according to ages. Historically relevant dates: - - - = AD 1242 (drawing up the "Golden Bull" by King Bela IV); $\cdots \cdots=$ AD 1635-1650 (construction of the Convent of St. Clare).

Remains of older shallow sod houses overlain by dwellings with stone basements and stone hearths were found in the hall of the convent. Samples from this area of the excavation yielded confirming Hallstatt dates. Two fragments of dwelling posts (Z-2452: $2340 \pm 115 \mathrm{BP}$ and Z-2453: $2100 \pm 90 \mathrm{BP}$ ) (B), were also dated to the Hallstatt. Charcoal from a fireplace in a closed earth-hut at the opposite end of the hall (C) date to an older Hallstatt phase (Z-2454: $2375 \pm 105 \mathrm{BP})$.

The same age was established for a part of a board that covered the fireplace (D) (Z-2463: $2255 \pm$ $111 \mathrm{BP})$. The oldest date (9th to 6th century BC) was obtained for a fragment of a post (Z-2457: $2590 \pm 130 \mathrm{BP})$ from the earliest phase of a dwelling, which-according to the archaeological finds-corresponds to an older Hallstatt phase. A charcoal sample (Z-2458: $2450 \pm 110 \mathrm{BP}$ ) from the bottom of a pit surrounded by a stone wall and connected to another smaller pit that served as an ash depository dates to the same period. In one pit, a swine skull was found buried in clay. The assumed connection between the charcoal (Z-2459: $2290 \pm 105 \mathrm{BP})$ from an overlying pit (the so-called foundation pit) and sample Z-2457 (2590 $\pm 130 \mathrm{BP})$ was not confirmed by the ${ }^{14} \mathrm{C}$ dates. However, this connection is supported by the dates on samples Z-2455 (1990 $\pm 100 \mathrm{BP})$ and Z-2456 $(2110 \pm 100)$, which were $4 \mathrm{~cm}$ apart, lying in vertical positions and separated by a thin, but strong, layer of clay. The older layer seems to have been leveled during the reconstruction of the dwelling. Two samples stratigraphically associated with $\mathrm{La}$ Tène were found beneath the East wing of the convent. Sample Z-2460 (1745 $\pm 135 \mathrm{BP})(\mathrm{E})$ should be the continuation of the beams found outside the 
convent (Z-2482 to Z-2490). The second sample, Z-2461 $(1630 \pm 105 \mathrm{BP})(\mathrm{F})$, dated to the 4 th to 6 th century. No archaeological finds exist to support these dates.

The remains of a rampart (G) were found along the slope following the East wing of the convent to the promenade Vrazovo Setalište. The burned layer consisted of up to $50 \mathrm{~cm}$ of clay (average $30 \mathrm{~cm}$ ) overlying a foundation of timber that seems to have been burned deliberately to fire the clay and provide a solid base $c a .6 \mathrm{~m}$ wide for another clay fill into which the wooden posts of a palisade were driven.

As Figure 3 shows, the calibrated ages range from the 8 th to the 2 nd century $\mathrm{BC}$, and the most probable period when the trees were felled was between the 4th and 3rd century BC. However, tree-ring dates determined at Cornell University, based on the German Oak Chronology (Becker 1993), gave the best statistical fit at AD 679 (Durman 1994).

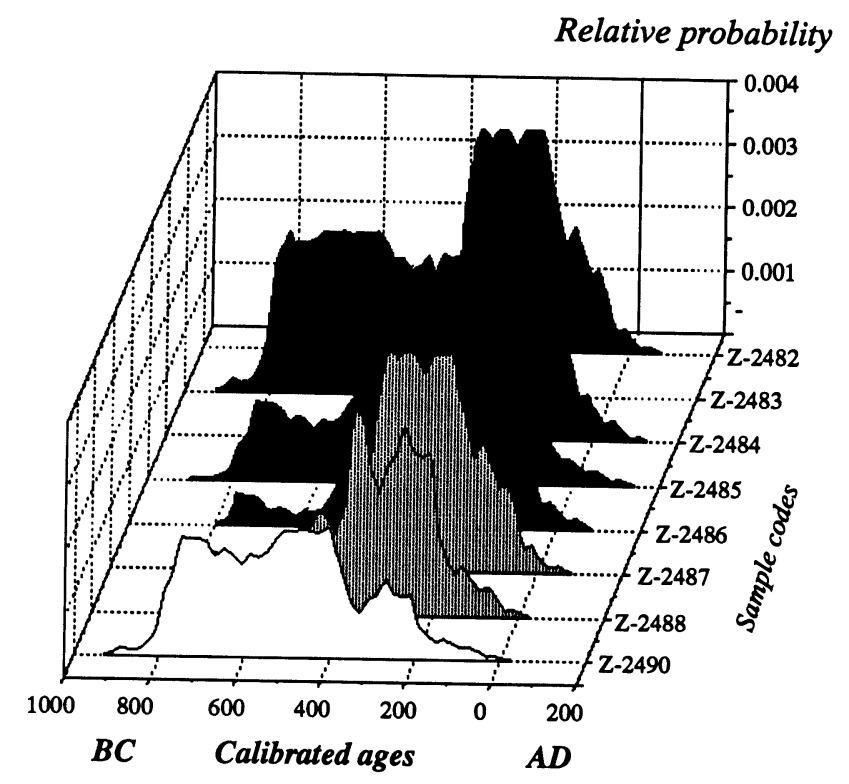

Fig. 3. Calibrated age ranges of the samples from Vrazovo Šetalište

At the site of the convent parlatorium a chapter-house (H) was standing in the Middle Ages. Boards, probably used as roof shingles, seem to have been thrown into a trench during the reconstruction of the house in the 15th century. Calibrated ages of samples Z-2280 (300 $\pm 75 \mathrm{BP}), \mathrm{Z}-2285(264 \pm 105$ $\mathrm{BP})$ and Z-2286 (325 $\pm 80 \mathrm{BP})$ fit the archaeological stratigraphy. However, tree-ring dates derived from the Cornell Tree-Ring Master Chronology gave the year AD 1171 (Durman 1994).

At the northwestern corner of the convent complex, where two trenches were excavated, several pieces of wood were ${ }^{14} \mathrm{C}$ dated. The top of the central post from the eastern trench was cut and the ${ }^{14} \mathrm{C}$ date of ten outer tree rings (Z-2369: $765 \pm 50 \mathrm{BP}$ ) ranged from cal $\mathrm{AD} 1222$ to 1279 . A tree-ring date from Cornell (Balkans) agrees with this result, giving $A D 1290$ for the youngest (outer) sapwood ring. A ${ }^{14} \mathrm{C}$ age of a well-preserved wooden board (Quercus) found between the two outer posts of the same trench spans from cal AD 1295 to 1400 (Z-2409: $605 \pm 80 \mathrm{BP})$. The earliest medieval result obtained by the ${ }^{14} \mathrm{C}$ method is for the board that was part of the door at the entrance to this trench (Z-2412: $795 \pm 90 \mathrm{BP})$. Between this construction period, which according to both ${ }^{14} \mathrm{C}$ and tree-ring dating should be $c a$. AD 1183-1289, and the construction of the convent in the 17th century, 
trenches were apparently filled with garbage. Twigs, a bone and sorghum from these trenches date from the 13th-16th century, as expected from archaeological observations.

From the western trench $(J)$ a wooden post (Z-2410: $440 \pm 80 \mathrm{BP})$ dated to the 15th century, which is surprisingly young when compared with the tree-ring date (AD 1292) of a tongue-and-groove board found near the same post. Excavations in the convent cloister uncovered several pits (K, L, M) that apparently served as garbage pits. Dates of wood samples from these pits confirm archaeological expectations, but we did not get a confirming date from a piece of straw (Z-2425: $120 \pm 80$ $\mathrm{BP})$ found in one of these pits. Only one sample was ${ }^{14} \mathrm{C}$ dated from the time of the construction of the convent ( $\mathrm{AD} 1635-1650)$. This result on a plank from an underground vault dating to the time of construction (Z-2408: $216 \pm 119 \mathrm{BP})$ was not satisfactory due to the large range in calibrated ages caused by the relatively large standard deviation.

\section{ConClusion}

Systematic archaeological excavations at the Zagreb Upper Town showed that this site was inhabited much earlier than expected. The series of ${ }^{14} \mathrm{C}$ ages from the Zagreb Upper Town generally confirmed the cultural periods determined by archaeological dating methods. The ${ }^{14} \mathrm{C}$ ages of the Middle Age samples agree well with the historical data and support the archaeological assumption that the first ramparts of the medieval town were constructed in the 12th and 13th centuries. A discrepancy exists for the samples associated with the construction of the rampart at the eastern part of the site (Z-2482 to Z-2490). Dendrochronological measurements gave a best fit in the year AD 678, as opposed to ${ }^{14} \mathrm{C}$ results, which consistently point to the La Tène period. Whether the reason for this discrepancy lies in the use of the South German Oak Chronology for trees deriving from the Pannonian Valley will be tested in the future by further comparisons of ${ }^{14} \mathrm{C}$ and tree-ring dating.

\section{ACKNOWLEDGMENTS}

This work was supported by Grant 1-07-064 from the Ministry of Science, Republic of Croatia. The authors wish to thank E. Hernaus for technical assistance in sample preparation.

\section{REFERENCES}

Becker, B. 1993 An 11,000-year German oak and pine dendrochronology for radiocarbon calibration. In Stuiver, M., Long, A. and Kra, R. S., eds., Calibration 1993. Radiocarbon 35(1): 201-214.

Durman, A. (ms.) 1994 Cornell University Dendrochronological Laboratory internal report.

Horvatinżic, N., Obelic, B., Krajcar Bronić, I., Srdoč, D. and Bistrovic, R. 1995 Sources of radon contamination in ${ }^{14} \mathrm{C}$ dating. Radiocarbon, this issue.

Krajcar Bronić, I., Horvatinčić, N., Obelic, B., Bistrovic, R. 1995 Radiocarbon intercomparison studies at the Ruđjer Boškovic Institute. Radicarbon, this issue.

Longin, R. 1971 New method of collagen extraction for radiocarbon dating. Nature 230(2): 231-242.

Mook, W. G. 1986 Business meeting: Recommendations/ resolutions adopted by the Twelfth International Radiocarbon Conference. In Stuiver, M. and Kra, R. S., eds., Proceedings of the 12 th International ${ }^{14} \mathrm{C}$ Conference. Radiocarbon 28(2A): 799.

Obelic, B. 1989 The radiocarbon data base at Ruđer
Bošković Institute Radiocarbon Laboratory. In Stuiver, M., Kra, R. S. and Srdox, D., eds., Proceedings of the 13th International ${ }^{14} \mathrm{C}$ Conference. Radiocarbon 31 (3): 1057-1062.

Scott, E. M., Aitchison, T. C., Harkness, D. D., Cook, G. T. and Baxter, M. S. 1990. An overview of all three stages of the International Radiocarbon Intercomparisons. In Scott, E. M., Long, A. and Kra, R. S., eds., Proceedings of the International Workshop of Intercomparison of ${ }^{14} \mathrm{C}$ Laboratories. Radiocarbon 32(3): 309-320.

Srdoč, D., Breyer, B. and Sliepčevic, A. 1971 Ruđjer Boక̌kovic Institute radiocarbon measurements I. $R a$ diocarbon 13(1): 135-140.

Stuiver, M. and Polach, H. 1977 Discussion: Reporting of ${ }^{14} \mathrm{C}$ data. Radiocarbon 19(3): 355-363.

Stuiver, M. and Reimer, P.J. 1993 Extended ${ }^{14} \mathrm{C}$ data base and revised CALIB $3.0{ }^{14} \mathrm{C}$ age calibration. In Stuiver, M., Long, A. and Kra, R. S., eds., Calibration 1993. Radiocarbon 35(1): 215-230. 